\title{
Pengaruh Keputusan Pendanaan, Keputusan Investasi dan Kebijakan Dividen Terhadap Nilai Perusahaan
}

\author{
Roysul Hakiki ${ }^{1}$, Muninghar ${ }^{2}$ \\ Universitas Wijaya Putra Surabaya \\ muningsuma850@gmail.com
}

\begin{abstract}
The research aims to test and analyze the effect of funding decisions, investment decisions and dividend policies on corporate value. The company that became the analysis unit is a manufacturing company, Tbk sub-sector of Basic Industry and Chemicals and Various Industries. Sampling uses purposive sampling with criteria from researchers. The data is analyzed using SPSS tools. Test results found that partial funding decisions and investment decisions had a significant effect on the value of the company, while dividend policies had no significant effect on the value of the company. Other results also revealed simultaneous funding decisions, investment decisions and dividend policies had a significant effect on corporate value.
\end{abstract}

Keywords: Funding decesion, Investment decision, dividend policy, corporate value.

\begin{abstract}
Abstrak: Penelitian ini bertujuan untuk menguji dan menganalisis pengaruh keputusan pendanaan, keputusan investasi dan kebijakan dividen terhadap nilai perusahaan. Perusahaan yang menjadi unit analisis adalah perusahaan manufaktur, Tbk sub sektor Industri Dasar dan Kimia Serta Aneka Industri. Pengambilan sampel menggunakan purposive sampling dengan kriteria dari peneliti. Data dianalisis menggunakan alat bantu SPSS. Hasil pengujian menemukan bahwa secara parsial keputusan pendanaan dan keputusan investasi berpengaruh signifikan terhadap nilai perusahaan, sedangkan kebijakan dividen tidak berpengaruh signifikan terhadap nilai perusahaan. Hasil lainnya juga mengungkapkan secara simultan keputusan pendanaan, keputusan investasi dan kebijakan dividen berpengaruh signifikan terhadap nilai perusahaan.
\end{abstract}

Kata Kunci: Keputusan pendanaan, keputusan investasi, kebijakan dividen, nilai perusahaan. 


\section{PENDAHULUAN}

Tujuan utama perusahaan adalah meningkatkan nilai perusahaan melalui peningkatan kemakmuran politik pemegang saham. Pemegang saham, kreditur dan manajer adalah pihak-pihak yang perbedaan kepentingan yang perspektif berkenaan dengan perusahaan. Pemegang saham akan cenderung memaksimalkan nilai saham yang memaksa manajer untuk bertindak sesuai kepentingan mereka melalui pengawasan yang mereka lakukan. Kreditur disisi lain cenderung akan berusaha melindungi dana yang sudah mereka investasikan dalam perusahaan dengan jaminan dan kebijakan pengawasan yang ketat pula. Manajer juga memiliki dorongan untuk mengejar kepentingan pribadi mereka. Bahkan tertutup kemungkinan para manajer melakukan investasi walaupun investasi tersebut tidak memaksimalkan nilai pemegang saham.

Untuk mencapai tujuan meningkatkan nilai perusahaan maka dibutuhkan lah seorang manajer yang mampu untuk mengambil keputusan keuangan yang tepat. Salah satukeputusan keuangan yang diambil oleh seorang manajer adalah keputusan investasi. Keputusan investasi sangat penting karena akan mempengaruhi keberhasilan dalam mencapai tujuan perusahaan. Jika perusahaan mampu menciptakan keputusan investasi yang tepat maka aset perusahaan akan menghasilkan kinerja yang optimal sehingga memberikan sinyal positif bagi investor yang nantinya 20 akan meningkatkan harga saham dan menaikkan nilai perusahaan (Arzal dan Rohman, 2012). Keputusan investasi dalam penelitian ini diproksikan dengan Price Earnings Ratio (PER) yang merupakan indikasi penilaian pasar modal terhadap kemampuan perusahaan dalam menghasilkan laba/keuntungan potensialperusahaan di masa datang. Rasio ini menunjukkan seberapa banyakinvestor bersedia membayar untuk setiap laba yang dilaporkan (Brigham dan Houston, 2011). Makin besar price earnings ratio suatu saham maka harga saham tersebut akan semakin mahal terhadap pendapatan bersih per sahamnya. PER juga merupakan rasio yang menunjukkan tingkat pertumbuhan perusahaan. PER yang tinggi menunjukkan prospek pertumbuhan perusahaan yang bagus dan risikonya rendah (Septia, 2015).

Keputusan lain yang dapat mempengaruhi nilai perusahaan adalah keputusan pendanaan, keputusan pendanaan juga dapat mengoptimalkan nilai perusahaan. Keputusan pendanaan berkaitan dengan keputusan perusahaan dalam mencari dana untuk membiayai investasi dan menentukan komposisi sumber pendanaan (Kumar et al., 2012). Pendanaan perusahaan dapat dikelompokkan berdasarkan sumber dananya yaitu sumber dana internal dan sumber dana eksternal. Efni (2011) menyatakan bahwa pendanaan internal merupakan pendanaan yang berasal dari dalam perusahaan berupa laba ditahan sedangkan pendanaan eksternal yaitu pendanaan hutang, ekuitas, dan hybrid securities. Menurut Kusumaningrum et al. (2013) keputusan pendanaan menyangkut tentang bagaimana memperoleh dana untuk membiayai investasi yang efisien, bagaimana menentukan komposisi sumber dana optimal bagi perusahaan dan bagaimana komposisi optimal itu harus dipertahankan serta apakah perusahan sebaiknya menggunakan modal 
asing atau modal sendiri. Keputusan pendanaan dalam penelitian ini diproksikan dengan Debt to Equity Ratio (DER) dimana rasio ini menunjukkan perbandingan antara pembiayaan dan pendanaan melalui hutang dan melalui ekuitas. Keputusan pendanaan yang menggunakan pendanaan melalui ekuitas lebih banyak daripada pendanaan melalui hutang karena dengan menggunakan pendanaan melalui ekuitas lebih banyak dapat meningkatkan nilai perusahaan (Wijaya dan Wibawa, 2010).

Pada penelitian Sartini dan Purbawangsa (2016) kebijakan dividen memiliki pengaruh posotif terhadap nilai perusahaan, namun hasil penelitian tersebut tidak sejalan dengan hasil penelitian Alvita dan Khairunnisa (2019), yang menyatakan bahwa kebijakan dividen tidak berpengaruh terhadap nilai perusahaan. Sektor industri manufaktur memiliki peran penting bagi masyarakat. Sektor ini bekerja untuk menghasilkan barang yangsesuai dengan kebutuhan kosumen, dimana proses produksi dilakukan untuk mengubah bahan mentah menjadi barang jadi atausiap pakai. Hal ini memaksa perusahaan untuk terus berinovasi dalam segi kualitas dan harga demi menarik minat konsumern. Aktivitas operaional perusahaan tersebut akan tercermin pada laporan keuangan. Melalui laporan keuangan inilah investor mampu menilai kinerja perusahaan dimasa yang akan datang. Berdasarkan uraian latar bealakang diatas maka, penulis tertarik untuk meneliti lebih lanjut tentang keputusan pendanaan, keputusan investasi, dan keputusan dividen serta nilai perusahaan.

\section{TINJAUAN TEORITIS}

\section{Nilai Perusahaan}

Nilai perusahaan merupakan kinerja perusahaan yang dicerminkan oleh harga saham yang dibentuk oleh permintaan dan penawaran di pasar modal yang merefleksikan penilaian masyarakat terhadap kinerja perusahaan Harmono (2014) Nilai perusahaan dapat tercermin dari harga pasar, dimana harga pasar yang tinggi dapat menarik investor untuk berinvestasi di perusahaan. Menurut (Sujoko dan Soebiantoro, 2007) nilai perusahaan merupakan presepsi investor terhadap perusahaan, yang sering dikaitkan dengan harga saham. Nilai perusahaan dapat didefinisikan sebagai presepsi investor terhadap keberhasilan manajemen mengelola perusahaan.

\section{Keputusan Pendanaan}

Keputusan Pendanaan merupakan keputusan mengenai sumber dana yang akan digunakan oleh perusahaan. Keputusan pendanaan adalah kebijakan yang menganalisis kondisi sumber pendanaan perusahaan baik melalui utang maupun modal yang akan dialokasikan untuk mendukung aktivitas operasi perusahaan. menurut Harmono (2014) Sumber pendanaan dibagi menjadi dua jenis yaitu sumber pendanaan internal dan sumber pendanaan eksternal. Menurut Suroto (2015), Beberapa perusahaan lebih memilih 
pendanaan menggunakan hutang, karena dengan menggunakan hutang dapat mengurangi kewajiban pajak, hal ini dikarenakan bunga pinjaman merupakan biaya yang dibebankan kepada perusahaan.

\section{Kebijakan Dividen}

Kebijakan dividen memiliki peran yang penting dalam menjelaskan nilai perusahaan. Kebijakan dividen berkaitan dengan kebijakan mengenai seberapa besar laba yang diperoleh perusahaan yang akan didistribusikan kepada pemegang saham dalam bentuk dividen. Menurut Harmono (2014) kebijakan dividen adalah presentase laba yang dibayarkan kepada pemegang saham dalam bentuk dividen tunai, penjagaan stabilitas dividen dari waktu ke waktu, pembagian dividen saham, dan pembelian kembali saham.

\section{Keputusan Investasi}

Kebijakan investasi adalah kebijakan terpenting dari kedua kebijakan lain dalam manajemen keuangan. Investasi modal sebagai aspek utama kebijakan manajemen keuangan karena investasi adalah bentuk alokasi modal yang realisasinya harus menghasilkan manfaat atau keuntungan di masa yang akan datang (Harmono, 2014).

\section{METODOLOGI PENELITIAN}

\section{Jenis dan Pendekatan Penelitian}

Jenis penelitian ini menggunakan penelitian kuantitatif dengan pendekatan asosiatif, penelitian kuantitatif artinya metode penelitian yang digunakan untuk meneliti populasi atau sampel tertentu, pengumpulan data menggunakan instrumen penelitian, analisis data statistik dengan tujuan untuk menggambarkan dan menguji hipotesis yang telah ditetapkan (Sugiyono, 2017). Penelitian ini menggunakan pendekatan asosiatif, metode asosiatif adalah metode statistika yang digunakan untuk menguji hipotesis dan mengetahui hubungan antara satu variabel dengan variabel lainnya, atau bagaimana suatu variabel mempengaruhi variabel lain.

Jenis data yang digunakan dalam penelitian ini adalah data sekunder yang berupa lapaoran keuangan perusahaan-perusahaan yang terdaftar di Bursa Efek Indonesia. Datadata tersebut diperoleh dari situs resmi Bursa Efek Indonesia (BEI) yaitu https://www.idx.co.id. Data-data dalam penelitian ini dikumpulkan dengan dokumentasi dilakukan dengan sumber data yang didokumentasikan perusahaan seperti laporan tahunan perusahaan. Studi pustaka menggunakan berbagai literatur seperti jurnal, Artikel, dan literatur lain yang berhubungan dengan pembahasan dalam peneliti. 


\section{HASIL DAN PEMBAHASAN}

Analisis deskriptif dari data yang diambil untuk penelitian ini adalah dari 2017 sampai dengan tahun 2019 yaitu sebanyak 13 data pengamatan. Deskripsi variable dalam statistic deskriptif yang digunakan pada penelitian ini meliputi nilai minimum, nilai maksimun, mean, dan standardevisiasi. Berdasarkan hasil pengolahan data pada deskriptif dapat diketahui bahwa jumlah data yang digunakan dalam penelitian adalah 39 data, dan hasil perhitungan pada hasil analisis deskriptif tersebut adalah sebagai berikut :

1. Variabel DER (keputusan pendanaan) memiliki nilai minimum sebesar 0,10 dimiliki oleh perusahaan (PT Indosping Tbk, pada tahun 2019) dan memiliki nilai maksimum sebesar 6.09 dimiliki oleh perusahaan PT Semen Indonesia (Persero) Tbk pada tahun 2017). Nilai rata-rata (mean) sebesar 0.8931 dan memiliki nilai standart deviasi sebesar 1.09261.

2. Variabel PER (keputusan investasi) memiliki nilai minimum sebesar 4,13 dimiliki oleh perusahaan (PT KMI Wire and Cable Tbk, pada tahun 2019) dan memiliki nilai maksimum sebesar 172.80 dimiliki oleh perusahaan PT Semen Indonesia (Persero) Tbk pada tahun 2018. Nilai rata-rata (mean) sebesar 49.0605dan memiliki nilai standart deviasi sebesar 49.50379.

3. Variabel DPR (kebijakan dividen) memiliki nilai minimum sebesar 0,03 dimiliki oleh perusahaan (PT Indosping Tbk, pada tahun 2019) dan memiliki nilai maksimum sebesar 4,20 dimiliki oleh perusahaan (PT Selamat Sempurna Tbk pada tahun 2018). Nilai rata-rata (mean) sebesar 1,0805dan memiliki nilai standart deviasi sebesar $1,03833$.

4. Variabel PBV (Nilai perusahaan) memiliki nilai minimum sebesar 0,03 dimiliki oleh perusahaan (PT Semen Indonesia (Persero) Tbk, pada tahun 2017) dan memiliki nilai maksimum sebesar 7,69 dimiliki oleh perusahaan (PT Indosping Tbk pada tahun 2019). Nilai rata-rata (mean) sebesar 1,7138dan memiliki nilai standart deviasi sebesar 1,96481 .

\section{Uji Asumsi Klasik}

Uji asumsi klasik dilakukan untuk mengetahui asumsi-asumsi yang diperlukan dalam analisi regresi linier berganda sudah terpenuhi. Uji asumsi klasik dilakukan untuk memperoleh hasil yang valid. Uji asumsi klasik dalam penelitian ini terdiri dari uji normalitas, uji multikolonearitas, uji autokorelasi dan uji heterokedastisitas.

\section{Uji Normalitas Data}

Uji Normalitas data dilakukan untuk mengetahui apakah variable dependen dan independen berdistribusi normal atau tidak. Model regresi yang baik adalah memiliki distribusi residual normal atau mendekati normal. Uji normalitas pada penelitian ini 
menggunakan One Sampel Kolmogorov-Smirnov. Berdasarkan hasil pengujian didapatkan informasi bahwa nilai Asymp.Sig (2-tailed) sebesar 0,231 lebih besar dari 0,05 maka dapat disimpulkan bahwa data berdistribusi normal. Dengan demikian asumsi atau pertanyaan normalitas dalam model regresi sudah terpenuhi.

\section{Uji Multikolinieritas}

Adanya multikolinieritas dapat dilihat pada hasil olah data Coefficients pada kolom Collinierity Statistics yang ditunjukan dengan nilai VIF (Variance Inflation Factor) dan nilai Tolerance .

a Apabila nilai tolerance menunjukkan $>0,1$ dan $\mathrm{VIF}<10$ maka dapat disimpulkan bahwa tidak terjadi multikoliniearitas, sedangkan

b. Apabila nilai tolerance menunjukkan $<0,1$ dan VIF $>10$ maka dapat disimpulkan bahwa terjadi multikoliniearitas.

Berdasarka hasil olah data menunjukan bahwa tolerance dan VIF sebagai berikut :

- Keputusan Pendanaan nilai tolerance sebesar 0,977 dan VIF sebesar 1,023.

- Keputusan Investasi nilai tolerance sebesar 0,842 dan VIF sebesar 1,138.

- Kebijakan Dividen nilai tolerance sebesar 0,844 dan VIF sebesar 1,833.

Hal ini menunjukan bahwa nilai tolerance $>0,1$ danVIF $<10$ sehingga variabel penelitian bebas dari masalah multikolinieritas.

\section{Uji Autokorelasi}

Uji autokorelasi digunakan untuk menguji apakah sebuah model regresi linier ada korelasi antara kesalahan pengganggu pada periode dengan kesalahan penganggu pada periode t-1 (sebelumnya). Hasil uji Durbin-Wason pada penelitian ini menunjukkan nilai DW sebesar 1,580 yaitu berada diantara angka -2 sampai +2 . Dengan demikian model regresi yang akan digunakan tidak terjadi autokorelasi.

\section{Uji Heterokedastisitas}

Pengujian heteroskedastisitas data bertujuan untuk mengetahui apakah di dalam regresi terjadi ketidaksamaan variance antara residual pengamatan satu dengan residual pengamatan lainnya. Hasil diketahui bahwa nilai signifikan ketiga variabel independen lebih dari 0,05. Dengan demikian dapat disimpulkan bahwa tidak terjadi masalah heteroskedastisitas pada model regresi.

Selanjutnya adalah analisis regresi linier berganda yang dilakukan untuk melihat seberapa besar keputusan pendanaan, keputusan investasi, dan kebijakan dividen terhadap nilai Perusahaan pada perusahan manufaktur sub industri dasar dan kimia serta aneka industriyang terdaftar di Bursa Efek Indonesia daritahun 2017-2019. 
Regresi Linear Berganda berfungsi untuk menganalisis keterkaitan dan keterhubungan diantara dua atau lebih variable penelitian yang berbeda, yaitu variable dependen (terikat) dan variable independen (bebas). Berdasarkan hasil dari pengolahan data maka diperoleh persamaan regresi sebagai berikut:

$$
\mathrm{Y}=1.863-0,597 \mathrm{X} 1+0.018 \mathrm{X} 2-0,476 \mathrm{X} 3
$$

Dari persamaan regresi linier berganda diatas dapat dijelaskan sebagai berikut :

a. Nilai konstanta $(\alpha)$ sebesar 1.869 halini menyatakan bahwa nilai perusahaan pada perusahaan manufaktur sub sektor industri dasar dan kimia serta aneka industri yang terdaftar di Bursa Efek Indonesia (BEI) akan mengalami kenaikan 1.869 jika variabel Keputusan Pendanaan (X1), Keputusan Investasi (X2) dan Kebijakan Dividen (X3) bernilai konstan atau 0 (nol).

b. Nilai koefisien regresi variable keputusan pendanaan (X1) sebesar-0.597 hal ini menunjukkan bahwa setiap kenaikan keputusan pendanaan satu- satuan maka variable nilai perusahaan pada perusahaan manufaktur sub sektor industri dasar dan kimia serta aneka industri yang terdaftar di Bursa Efek Indonesia (BEI) mengalami peningkatan sebesar -0.597 dengan asumsi bahwa pada variable bebas yang lain dari model regres iadalah tetap.

c. Nilai koefisien regresi variable keputusan investasi (X2) sebesar 0.018 hal ini menunjukkan bahwa setiap kenaikan keputusan investasi satu- satuan maka variable nilai perusahaan pada perusahaan manufaktur sub sektor industri dasar dan kimia serta aneka industri yang terdaftar di Bursa Efek Indonesia (BEI) mengalami peningkatan sebesar 0.018 dengan asumsi bahwa pada variable bebas yang lain dari model regresi adalah tetap.

d. Nilai koefisien regresi variable kebijakan dividen (X3) sebesar -0.476 hal ini menunjukkan bahwa setiap kenaikan kebijakan dividen satu-satuan maka variable nilai perusahaan pada perusahaan manufaktur sub sektor industri dasar dan kimia serta aneka industri yang terdaftar di Bursa Efek Indonesia (BEI) mengalami peningkatan sebesar -0.476 dengan asumsi bahwa pada variable bebas yang lain dari model regresi adalah tetap.

\section{Uji Hipotesis}

Pengujian hipotesis merupakan pengujian yang digunakan untuk mengetahui ada tidaknya pengaruh keputusan pendanaan, keputusan investasi dan kebijakan dividen terhadap nilai perusahaan pada perusahaan manufaktur sub sector industri dasar dan kimia serta aneka industri yang terdaftar di BEI pada tahun 2017-2019 dengan significance level $0,05(\alpha=5 \%)$. 


\section{Uji t (Uji Secara Parsial)}

Uji t digunakan untuk menguji signifikan sikonstanta pada setiap variable bebas atau melakukan uji secara parsial (individu) untuk mengetahui pengaruh setiap variable bebas terhadap variable terikat. Hasil uji t dapat dijelaskan pada uraian berikut ini:

1. Nilai t keputusan pendanaan sebesar -2.281. Sedangkan nilai ( $\mathrm{p}$-value $=0,029<$ $0,05)$. Dengan demikian nilai ini memberikan makna bahwa secara parsial variable keputusan pendanaan berpengaruh signifikan terhadap nilai perusahaan pada perusahaan manufaktur sub sektor industri dasar dan kimia serat aneka industri yang terdaftar di Bursa Efek Indonesia pada tahun 2017- 2019.

2. Nilai t keputusan investasi sebesar 2.943. Sedangkan nilai ( $p$-value $=0,006<0,05$ ). Dengan demikian nilai ini memberikan makna bahwa secara parsial variable keputusan investasi berpengaruh signifikan terhadap nilai perusahaan pada perusahaan manufaktur sub sektor industri dasar dan kimia serat aneka industri yang terdaftar di Bursa Efek Indonesia pada tahun 2017- 2019.

3. Nilai t kebijakan dividen sebesar -1.807. Sedangkan nilai ( $\mathrm{p}$-value $=0,117<0,05$ ). Dengan demikian nilai ini memberikan makna bahwa secara parsial variable kebijakan dividen tidak berpengaruh signifikan terhadap nilai perusahaan pada perusahaan manufaktur sub sektor industri dasar dan kimia serta aneka industri yang terdaftar di Bursa Efek Indonesia pada tahun 2017- 2019.

\section{Uji F (Uji Secara Simultan)}

Pengujian kelayakan model dilakukan dengan menggunakan ANOVA (uji F). Digunakan untuk menguji apakah variabel bebas mempunyai pengaruh secara bersamasama terhadap variabel terikat. Pengaruh variabel bebas yang terdiri atas keputusan pendanaan, keputusan investasi dan kebijakan dividen secara bersama-sama terhadap nilai perusahaan. Adapun kriteria pengujian secara simultan dengan tingkat signifikansi $\alpha=5 \%(0,05)$ sebagai berikut:

1. Jika nilai signifikansi uji $\mathrm{F}>0,05$ uji model penelitian tidak layak untuk diuji.

2. Jika nilai signifikansi uji $\mathrm{F} \leq 0,05$ uji model penelitian layak untuk diuji.

Dari hasil tabel 4.8 diperoleh nilai uji F sebesar 4.455. Dengan nilai signifikansinya sebesar $0,009<0.05$, dengan demikian pada penelitian ini terdapat pengaruh yang signifikan antara variable independen (keputusan pendanaan, keputusan investasi dan kebijakan dividen) secara bersama-sama terhadap variabel dependen (nilai perusahaan) pada perusahaan manufaktur sub industri dasar dan kimia serat aneka industri yang terdaftar di Bursa Efek Indonesia periode 2017- 2019.

Dari hasil tabel diatas diperoleh nilai koefisien determinasi (Adjusted $\mathrm{R}$ square) sebesar 0,214 . Hal ini menunjukkan bahwa $21,4 \%$ nilai perusahaan dipengaruhi oleh 
keputusan pendanaan, keputusan investasi dan kebijkan dividen dan sisanya $78.6 \%$ dipengaruhi oleh variabel lain diluar dari variabel yang digunakan dalam penelitian ini.

\section{Pembahasan}

\section{Pengaruh Keputusan Pendanaan Terhadap Nilai Perusahaan}

Berdasarkan hasil pengujian pengaruh keputusan pendanaan (DER) terhadap nilai perusahaan (PBV), dengan nila signifikan sebesar 0,029. Karena nilai signifikan 0,029< 0,05 artinya variabel bebas keputusan pendanaan (DER) berpengaruh terhadap nilai perusahaan (PBV) Hal ini menandakan bahwa hipotesis dalam penelitian ini diterima. Hasil penelitian ini sejalan dengan Sartini dan Purbawangsa (2016) dengan judul pengaruh keputusan investasi, kebijakan dividen dan keputusan pendanaan terhadap nilai perusahaan yang hasil penelitiannya mengatakan bahwa keputusan pendanaan signifikan terhadap nilai perusahaan. Keputusan pendanaan yang diproksikan dengan debt to equty ratio mempengaruhi nilai perusahaan di mata pasar, dimana nilai perusahaan akan lebih tinggi jika sumber dana yang dimiliki perusahaan berasal dari modal atau equitas. Hasil penelitian ini juga sejalan dengan beberapa hasil studi yang lain seperti Triani \& Tarmidi (2019) dan Sumarau (2019) yang menyatakan bahwa peningkatan keputusan pendanaan dapat meningkatkankan nilai perusahaan yang lebih baik. Selain itu, hasil studi ini bertentangan dengan hasil penelitian Sihwahjoeni et al. (2020) yang menyatakan keputusan pendanaan tidak memiliki pengaruh terhadap nilai perusahaan.

\section{Pengaruh Keputusan Investasi Terhadap Nilai Perusahaan}

Berdasarkan hasil pengujian pengaruh keputusan investasi (PER) terhadap nilai perusahaan (PBV), dengan nila signifikan sebesar 0,006. Karena nilai signifikan 0,006 < 0,05 artinya variabel bebas keputusan investasi (PER) berpengaruh terhadap nilai perusahaan (PBV). Hal ini menandakan bahwa hipotesis dalam penelitian ini diterima. Hasil penelitian ini sejalan dengan hasil penelian Sartini dan Purbawangsa (2016) yang mengatakan bahwa keputusan investasi berpengaruh signifikan terhadap nilai perusahaan. Meningkatnya keputusan investasi pada pemegang saham ataupun investor yang berasal dari luar perusahaan tidak selamanya mempengaruhi nilai perusahaan. Hasil penelitian ini juga mendukung teori sinyal (signaling theory), menurut Brigham dan Houston dalam Fenandar dan Raharja (2010) dimana investasi akan memberi sinyal tentang pertumbuhan pendapatan perusahaan yang diharapkan dimasa mendatang dan mampu meningkatkan nilai pasar saham perusahaan.

\section{Pengaruh Kebijakan Dividen Terhadap Nilai Perusahaan}

Berdasarkan hasil pengujian pengaruh kebijakna dividen (DPR) terhadap nilai perusahaan (PBV), dengan nilai signifikan sebesar 0,117. Karena nilai signifikan 0,117 > 
0,05 artinya variabel bebas kebijakan dividen (DPR) tidak berpengaruh terhadap nilai perusahaan (PBV). Hal ini menandakan bahwa hipotesis dalam penelitian ini ditolak. Hasil penelitian ini sejalan dengan Piristin \& Khairunnisa (2019) dengan judul analisis pengaruh kebijakan dividen, keputusan investasi dan keputusan pendanaan terhadap nilai perusahaan yang mengatakan bahwa kebijakan dividen tidak berpengaruh signifikan terhadap nilai perusahaan. Hal ini tidak menjadikan kebijakan dividen menjadi faktor utama yang menjadi pertimbangan bagi investor untuk menanamkan modalnya pada perusahaan. Penelitian ini dapat diartikan sesuai dengan teori menurut Kamaludin (2011:334) yang memngungkapkan bahwa pembayaran dividen yang tinggi tidak mempengaruhi pemegang saham dan pengaruh pembayaran dividen kepada pemegang saham akan diimbangi dengan jumlah yang sama dengan cara pembelanjaan atau pemenuhan dana yang lain.

\section{Pengruh Keputusan Pendanaan, Keputusan Investasi dan Kebijakan Dividen Terhadap Nilai Perusahaan}

Dari hasil pengujian secara simultan diperoleh nilai uji $\mathrm{F}$ sebesar 4.455. Dengan nilai signifikansinya sebesar $0,009<0.05$, dengan demikian pada penelitian ini terdapat pengaruh yang signifikan antara variable independen (keputusan pendanaan, keputusan investasi dan kebijakan dividen) secara simultan terhadap variabel dependen (nilai perusahaan). Hasil ini sejalan dengan temuan penelitian Triani \& Tarmidi (2019) yang mempresentasikan bahwa keputusan pendanaan, keputusan investasi dan kebijakan dividen berpengaruh secara positif dan signifikan dalam meningkatkan nilai perusahaan.

\section{Simpulan}

1. Keputusan pendanaan terbukti berpengaruh secara positif dan signifikan terhadap nilai perusahaan pada perusahaan manufaktur ub Sektor Industri Dasar dan Kimia serta Aneka Industri yang terdaftar di BEI pada tahun 2017-2019.

2. Keputusan investasi berpengaruh secara positif dan signifikan terhadap nilai perusahaan pada perusahaan manufaktur ub Sektor Industri Dasar dan Kimia serta Aneka Industri yang terdaftar di BEI pada tahun 2017-2019.

3. Kebijakan dividen berpengaruh positif dan tidak signifikan terhadap nilai perusahaan pada perusahaan manufaktur ub Sektor Industri Dasar dan Kimia serta Aneka Industri yang terdaftar di BEI pada tahun 2017-2019.

4. Keputusan pendanaan, keputusan investasi, dan kebijakan dividen secara simultan berpengaruh secara positif dan signifikan terhadap nilai perusahaan pada perusaahaan manufaktur sub Sektor Industri Dasar dan Kimia serta Aneka Industri yang terdaftar di BEI pada tahun 2017-2019. 


\section{SARAN}

Hasil penelitian ini memiliki banyak keterbatasan-keterbatasan yang mungkin perlu untuk disempurnakan di penelitian mendatang. Salah satunya adalah jumlah sampel yang kecil, sehingga penelitian mendatang perlu untuk memperluas cakupan objek penelitian sehingga memberikan tambahan sampel yang lebih besar dan dapat lebih digeneralisirkan, jika memungkinkan menggunakan seluruh perusahaan manufaktur yang terdaftar di Bursa Efek Indonesia karena dengan menambah sampel yang lebih besar, maka dapat dijadikan pembanding dan akan mendapatkan hasil yang lebih maksimal. Selain itu, bagi penelitian selanjutnya diharapkan menambah atau mengganti variabel yang dimungkinkan berpengaruh terhadap nilai perusahaan sehingga memperoleh hasil yang lebih baik, seperti kebijakan hutang, pertumbuhan perusahaan dan lain sebagainya.

\section{DAFTAR PUSTAKA}

Alvita, F., dan Khairunnisa. (2019). Analisis Pengaruh Kebijaan Dividen, Keputusan dan Keputusan Pendanaan terhadap Nilai Perusahaan. Bandung: Universitas Telkom Bandung

Arzal, Arie., dan Rohman, A. (2012). Pengaruh Keputusan Investasi, Keputusan Pendanaa, dan Kebijakan Deviden Terhadap Nilai Perusahaan. Diponegoro Jurnal Of Accunting, 1(2), 9-29

Brigham, E. F. dan Houston, J. F. (2011). Dasar-dasar Manajemen Keuangan Terjemahan. Edisi 10. Jakarta: Salemba Empat.

Bursa Efek Indonesia, Laporan Keuangan Tahunan,2017,2018, dan 2019. (diakses di https://www.idx.co.id)

Efni, Y. (2011). Pengaruh Keputusan Investasi, Keputusan Pendanaan, Kebijakan Dividen terhadap Nilai Perusahaan Studi pada Sektor Properti dan Real Estate di Bursa Efek Indonesia. Jurnal Aplikasi Manajemen, 6(6), 14-24.

Fenandar, G. I., dan Raharja, S. (2010). Pengaruh Keputusan Investasi, Keputusan Pendanaan Dan Kebijakan Deviden Terhadap Nilai Perusahaan. Diponegoro Journal Of Accounting, 1(2), 1-10.

Harmono. (2014). Manajemen Keuangan Berbasis balanced scored. Jakarta: PT Bumi Aksara.

Kamaludin. (2011). Manajemen Keuangan "Konsep Dasar dan Penerapannya". Bandung: Mandar Maju.

Kumar, S., Anjum, B., and Nayyar, S. (2012). Financing Decisions : Studi of Pharmaceutical Companies of India. International Journal of Marketing, Financial Services \& Management Research, 1(1): pp : 14-28. 
Kusumaningrum., Ratnasari, D. A., dan Rahardjo, S. N. (2013). Pengaruh Keputusan Investasi, Keputusan Pendanaan, Kebijakan Dividen, Kepemilikan Manajerial dan Kepemilikan Institusional Terhadap Nilai Perusahaan. Jurnal Ekonomika dan Bisnis, 2(4), 1-10.

Piristin, F. A \& Khairunnisa. (2019). Analisis Pengaruh Kebijakan Dividen, Keputusan Investasi Dan Keputusan Pendanaan Terhadap Nilai Perusahaan. Jurnal Aset (Akuntansi Riset), 11(1), 123-136

Sartini, L. P. N., dan Purbawangsa, I. B. A. (2016). Pengaruh Keputusan Investasi, Kebijakan Dividen dan Keputusan Pendanaan Terhadap Nilai Perusahaan Manufaktur di Bursa Efek Indonesia. Bali: Fakultas Ekonomi dan Bisnis Universitas Udayana.

Septia, A.W. (2015). Pengaruh Profitabilitas, Keputusan Investasi, Keputusan Pendanaan, dan Kebijakan Dividen terhadap Nilai Perusahaan pada Perusahaan Manufaktur yang Terdaftar Di Bursa Efek Indonesia. Skripsi, Yogyakarta: Universitas Negeri Yogyakarta.

Sihwahjoeni., Subiyantoro, E., \& Bili, M. R. (2020). Analysis Effect of Investment Decision, Financing and Dividend Policy on Value Company with Variable Business Risk as Mediation. International Journal of Research and Scientific Innovation (IJRSI), 7(7), 261-269

Sugiyono. (2017). Metode Penelitian Bisnis. Bandung: CV. Alfabeta.

Sujoko dan Soebiantoro, U. (2007). Pengaruh Struktur Kepemilikan Saham, Leverage, Faktor Interen dan Faktor Eksteren terhadap Nilai Perusahan. Jurnal Manajemen dan Kewirausahaan, 9(1), 28-45.

Sumarau, S. K. (2019). The effect of investment decisions, funding decisions, and profitability on manufacturing company value in indonesia stock exchange 20152018 PERIOD. Accountability, 8(2), 85-90

Suroto. (2015). Pengaruh Keputusan Investasi, Keputusan Pendanaan dan Kebijakan Dividen terhadap Nilai Perusahaan. Jurnal Ilmiah UNTAG Semarang,. 4(3), 2335 .

Triani, N., \& Tarmidi, D. (2019). Firm Value: Impact of Investment Decisions, Funding Decisions and Dividend Policies. International Journal of Academic Research in Accounting, Finance and Management Sciences, 9(2), 158-163

Wijaya, L.R.P, Wibawa, A. (2010). Pengaruh Keputusan Investasi, Keputusan Pendanaan, Dan Kebijakan Dividen Terhadap Nilai Perusahaan. Simposium Nasional Akuntansi XIII Purwokerto. 